\title{
LIGNOCELLULOSE-RICH SPENT MUSHROOM COMPOST FOR BIOSORPTION OF HEAVY METALS FROM EFFLUENT SAMPLES
}

\author{
PRIYA KATYAL, ${ }^{*}$ AVNEET KAUR ${ }^{*}$ and SUMITA CHANDEL ${ }^{* *}$ \\ "Department of Microbiology, Punjab Agricultural University, Ludhiana - 141004, Pb., India \\ ${ }^{* * *}$ Department of Soil Science, Punjab Agricultural University, Ludhiana - 141004, Pb., India \\ Corresponding author: Priya Katyal, drpkatyal@pau.edu
}

Received September 12, 2020

\begin{abstract}
Lignocellulose-rich spent mushroom compost (SMC) has been found to contain various functional groups that can be used for biosorption. Effluent samples collected from common effluent treatment plants (CETPs), i.e. Ludhiana Electroplaters Association (L-CETP) and Punjab Small Industries and Export Corporation (PSIEC) Leather Complex, Jalandhar (J-CETP), were analyzed for different waste water quality parameters, such as Dissolved Oxygen (DO), Biological Oxygen Demand (BOD), Chemical Oxygen Demand (COD) and heavy metal profile. Chromium was the dominant heavy metal in both samples, with a concentration of $226.62 \mathrm{ppm}$ in L-CETP and $1.83 \mathrm{ppm}$ in J-CETP. Spent compost of different cultivated mushrooms was analysed for its use in chromium biosorption by varying physicochemical parameters. Maximum removal of $\mathrm{Cr}$ was obtained at an initial metal concentration $(\mathrm{Ci})$ of $50 \mathrm{mg} / \mathrm{L}$, pH 6 and temperature of $25^{\circ} \mathrm{C}$. Experimental results were well fitted to the Langmuir and Freundlich isotherms. Fourier transform infrared (FT-IR) spectra showed a shift in peaks, indicating the functional groups involved in biosorption of chromium.
\end{abstract}

Keywords: biosorption, chromium, FT-IR, isotherms, CETP

\section{INTRODUCTION}

Rapid industrialization has resulted in the discharge of various organic contaminants into the environment, which affect ecosystems and human health. Heavy metals are considered to be more persistent than organic contaminants, such as pesticides or petroleum by-products, and are non-biodegradable. ${ }^{1-2}$ These metals can become mobile in the soil, depending on the soil $\mathrm{pH}$, and can leach to underground water reservoirs. ${ }^{3-4}$ The entry of heavy metals in the food chain can give rise to vital challenges threatening our ecosystems and human life, thus their removal from effluents is imperative, but it demands expensive clean-up procedures. Usually, heavy metals repress several essential enzymatic processes. Metals are associated with oxidation of proteins, by attaching themselves to the amino-acid residues present in these enzymes, as well as with inhibition of cell division and DNA damage. Heavy metals, such as mercury, silver and cadmium, can lead to toxic effects in organisms, when ingested even in trace amounts, and their maximum permissible limit in effluent discharge is $0.001 \mathrm{ppm}, 0.1 \mathrm{ppm}$ and 0.01 ppm, respectively. ${ }^{5}$ Considering the harmful effects of heavy metals on animals and human health, serious efforts need to be made for in-situ degradation of these recalcitrants.

In recent years, bioremediation has emerged as a cost-effective and eco-friendly method for transforming harmful, recalcitrant contaminants into environment-friendly and remedial byproducts by the action of varied microbiological treatments. This process involves two approaches: biosorption and bioaccumulation. Biosorption involves the use of cheap biomaterials and allows treating large volumes of wastewater, whereas bioaccumulation consists in removing heavy metals by the living cells of microorganisms, as they have better selectivity. Spent mushroom compost (SMC) is an unconventional biosorbent for heavy metals, such as cadmium, lead and chromium, due to the presence of hydroxyl, phosphoryl and phenolic functional groups on the outer side of the SMC. ${ }^{6}$ The utilisation of a spent mushroom substrate for heavy metal uptake combines the biosorption of heavy metals by the spent compost and the bioaccumulation of these recalcitrants by the impregnated fungal 
mycelium. ${ }^{7}$ The present study was conducted to explore the application of spent compost in effluent bioremediation and to contribute to finding an effective low-cost biosorbent.

\section{EXPERIMENTAL}

\section{Characterization of common effluent samples}

Effluent samples were collected from common effluent treatment plants located in Ludhiana and Jalandhar. After filtration through Whatmann filter paper No. 1, they were analysed in terms of various physico-chemical quality indicators, such as $\mathrm{pH}$, electrical conductivity (EC), total dissolved solids (TDS), total suspended solids (TSS), total hardness, dissolved oxygen (DO), biological oxygen demand (BOD5) and chemical oxygen demand (COD), as per standard methods. ${ }^{8}$ The metal profile of the effluent samples was estimated using Inductively Coupled Argon Plasma Atomic Emission Spectroscopy (ICAPAES).

\section{Standardisation of process parameters for biosorption of total chromium \\ Spent mushroom compost of Agaricus bisporus,} Pleurotus florida, Calocybe indica and Volvariella volvacea, received from the Mushroom Research Complex, Punjab Agricultural University, Ludhiana, was dried in an oven at $60{ }^{\circ} \mathrm{C}$ and ground to obtain a powder with particle size of 0.3-0.7 mm. Batch experiments were carried out in Erlenmeyer flasks to study the effect of various operating parameters, such as initial heavy metal concentration, $\mathrm{pH}$ and temperature, on biosorption of total chromium.

\section{Standard curve of chromium}

A stock solution of $\mathrm{Cr}$ (VI) was prepared by dissolving $2.83 \mathrm{~g}$ of $\mathrm{K}_{2} \mathrm{Cr}_{2} \mathrm{O}_{7}$ in $1000 \mathrm{~mL}$ of distilled water. From this stock solution, 50, 100, 200, 300, 400 and $500 \mathrm{ppm}$ solutions were prepared by using distilled water, and $0.2 \mathrm{~mL}$ of concentrated sulphuric acid was added to test tubes. The concentration of total $\mathrm{Cr}$ ionic species was measured by a UV visible double beam spectrophotometer at $440 \mathrm{~nm}^{9}$. The standard curve was plotted using metal concentration expressed in ppm and optical density at $440 \mathrm{~nm}$ (Fig. 1).

\section{Effect of pH, temperature and initial metal concentration on biosorption}

The initial $\mathrm{pH}$ of the potassium dichromate solution was varied in the range of 2-10 (adjusted by addition of $0.1 \mathrm{~N} \mathrm{HCl}$ and $\mathrm{NaOH}$ ). $2 \mathrm{~g}$ of spent mushroom compost of different white rot fungi was added to the $50 \mathrm{ppm}$ solution, under shaking at $250 \mathrm{rpm}$. The flasks were incubated at $25{ }^{\circ} \mathrm{C}$ for $2 \mathrm{~h}$. Another set of flasks was prepared by using $50 \mathrm{ppm} \mathrm{Cr}$ concentration, with an optimized $\mathrm{pH}$, and incubated at different temperatures $\left(15,25,35\right.$ and $\left.45^{\circ} \mathrm{C}\right)$ under shaking at $250 \mathrm{rpm}$.

Similarly, to optimize the substrate concentration, adsorption was studied in flasks by varying initial metal concentration, at the selected optimum $\mathrm{pH}$ and optimum temperature for each spent mushroom compost. The flasks were shaken at $250 \mathrm{rpm}$ for $2 \mathrm{~h}$. The filtrate was collected and samples were analyzed for $\mathrm{Cr}$ removal.

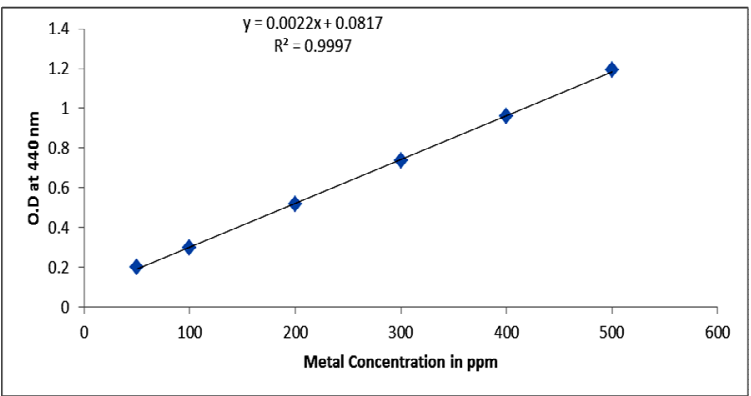

Figure 1: Standard curve for chromium estimation

\section{Adsorption isotherm}

The equilibrium of biosorption of heavy metals was modeled using adsorption isotherms. The Langmuir and Freundlich isotherms were applied to describe the adsorption equilibrium. The Langmuir adsorption isotherm is a nonlinear sorption model, which suggests that the uptake occurs on a heterogeneous surface by monolayer sorption without interaction between adsorbed molecules. In addition, it also assumes uniform energies of adsorption onto the surface. ${ }^{10}$ The linearized form of this model is the following:

$\mathrm{C}_{\mathrm{e}} / \mathrm{q}_{\mathrm{e}}=\mathrm{C}_{\mathrm{e}} / \mathrm{q}_{\max }+1 / \mathrm{bq}_{\max }$

where $C_{e}$ is the metal concentration at equilibrium, $q_{e}-$ the equilibrium metal biosorption uptake, $\mathrm{q}_{\max }-$ the maximum metal biosorption rate and $b$ - Langmuir constant. The values of $\mathrm{q}_{\max }$ and $\mathrm{b}$ were calculated from the slope and intercept of the graph. 
The Freundlich isotherm is a nonlinear adsorption model, which proposes monolayer sorption with heterogeneous distribution of active sites, accompanied by interactions between adsorbed molecules. The logarithmic form of this isotherm is:

$\log \mathrm{q}_{\mathrm{e}}=\log \mathrm{K}_{\mathrm{f}}+1 / \mathrm{n} \log \mathrm{C}_{\mathrm{e}}$

where $\mathrm{q}_{\mathrm{e}}$ and $\mathrm{C}_{\mathrm{e}}$ are the same as in Eq. (1), $\mathrm{K}_{\mathrm{f}}-$ Freundlich constant, indicating adsorption capacity and $\mathrm{n}$ - empirical constant. The values of $\mathrm{K}_{\mathrm{f}}$ and $\mathrm{n}$ were calculated from the intercept and slope of the graph, respectively.

\section{FTIR analysis}

FTIR analysis provides an insight into the adsorption process. The functional groups, involved in the adsorption process were determined by analyzing the peaks obtained. Differences in the peaks of the spent mushroom substrate before and after adsorption can be investigated by Fourier transform infrared spectroscopy. Metal binding was indicated by the shift in the ratio of the peaks related to protonated and dissociated carboxyl groups. These peaks reveal the important groups involved in the adsorption process. ${ }^{11}$

Fourier transform infrared (FT-IR) spectroscopy (Model Thermo Nicolet, 6700 USA) was carried for Agaricus bisporus SMC to identify the characteristic functional groups participating in the biosorption of metal ions.

\section{RESULTS AND DISCUSSION Characterization of effluent samples from CETPs}

The sample collected from L-CETP was found to have an acidic $\mathrm{pH}$ value (2.3) because electroplating effluents are generated from washing, rinsing and batch dumps that contain soluble forms of various metal ions, such as brass, nickel, cadmium, zinc, copper etc. On the other hand, the sample from J-CETP was found to possess alkaline $\mathrm{pH}$ (8.64), as it caters the needs of tannery industry. Alkaline $\mathrm{pH}$ is related to the use of lime pelt during tanning (Table 1).

Table 1

Physicochemical and heavy metal profile of the effluent samples

\begin{tabular}{lccc}
\hline Parameters* & L-CETP & J-CETP & $\begin{array}{c}\text { Permissible limits } \\
\text { as per CPCB }\end{array}$ \\
\hline $\mathrm{pH}$ & $2.3 \pm 0.2$ & $8.64 \pm 0.1$ & $6.0-9.0$ \\
Colour & Green & $\begin{array}{c}\text { Deep brown } \\
\text { Clear }\end{array}$ & 40.0 \\
Temperature $\left({ }^{\circ} \mathrm{C}\right)$ & $24.8 \pm 0.2$ & $26.9 \pm 0.1$ & 2500 \\
EC $(\mu \mathrm{S} / \mathrm{cm})$ & $1849 \pm 3.3$ & $1061 \pm 1.4$ & $200-500$ \\
Total hardness $\left(\mathrm{mg} \mathrm{CaCO}_{3} / \mathrm{L}\right)$ & $779.29 \pm 0.2$ & $982.55 \pm 0.1$ & 100 \\
Total solids $(\mathrm{TS})(\mathrm{mg} / \mathrm{L})$ & $640.7 \pm 0.4$ & $964.8 \pm 0.1$ & 500 \\
Total dissolved solids $(\mathrm{TDS})(\mathrm{mg} / \mathrm{L})$ & $594.4 \pm 0.2$ & $756.9 \pm 0.2$ & - \\
DO $\left(\mathrm{mg} \mathrm{O}_{2} / \mathrm{L}\right)$ & $4.39 \pm 1.5$ & $9.20 \pm 1.6$ & 30 \\
BOD $(\mathrm{mg} \mathrm{O} / \mathrm{L})$ & $13.2 \pm 2.1$ & $71.5 \pm 1.6$ & 250 \\
COD $(\mathrm{mg} \mathrm{O} / \mathrm{L})$ & $320 \pm 0.2$ & $240 \pm 0.3$ & Permissible limit \\
& L-CETP & J-CETP & as per CPCB \\
Metals & & Concentration $(\mathrm{ppm})$ & \\
& & 0.06 & 0.2 \\
Arsenic $(\mathrm{As})$ & 0.06 & 5.65 & - \\
Boron $(\mathrm{B})$ & 10.05 & 38.88 & - \\
Calcium $(\mathrm{Ca})$ & 49.15 & 0.32 & 2.0 \\
Cadmium $(\mathrm{Cd})$ & 0.02 & 1.83 & 0.1 \\
Chromium $(\mathrm{Cr})$ & 226.62 & 0.01 & 3.0 \\
Cobalt $(\mathrm{Co})$ & 0.14 & 0.56 & 5.0 \\
Copper $(\mathrm{Cu})$ & 7.07 & 20.34 & 3.0 \\
Iron $(\mathrm{Fe})$ & 2189.67 & 215.33 & - \\
Magnesium $(\mathrm{Mg})$ & 159.44 & 0.10 & 2.0 \\
Manganese $(\mathrm{Mn})$ & 26.38 & 0.10 & 3.0 \\
Nickel $(\mathrm{Ni})$ & 28.12 & 4.09 & - \\
Phosphorus $(\mathrm{P})$ & 158 & 0.39 & \\
Lead $(\mathrm{Pb})$ & 0.77 & & \\
Zinc $(\mathrm{Zn})$ & 20.03 & & \\
\hline
\end{tabular}

*Data represent mean of triplicate observations 
The colour of the electroplating industry effluent was green due to the presence of a high amount of nickel, iron and zinc, whereas the colour of the tannery effluent was deep brown due to the presence of tannic compounds and other impurities. A very high EC value was observed in the L-CETP sample due to the presence of a high level of salts of various metals in the effluent. Similarly, in the J-CETP sample, the EC value was $1061 \mathrm{mS} / \mathrm{cm}$, which was mainly due to the addition of a significant amount of sodium and chromium salts during the pickling and chrome tanning. The hardness of both effluent samples was very high $\left(779.29 \mathrm{mg}\right.$ equivalent $\mathrm{CaCO}_{3} / \mathrm{L}$ and $982.55 \mathrm{mg}$ equivalent $\mathrm{CaCO}_{3} / \mathrm{L}$ ) because of a high concentration of multivalent cations in water. Total solids were high in J-CETP $(964.8 \mathrm{mg} / \mathrm{L})$, as shown by the more pronounced turbidity, as compared to that of the L-CETP sample (640.7 $\mathrm{mg} / \mathrm{L})$. The values of total dissolved solids were observed to be high in the sample from J-CETP $(756.9 \mathrm{mg} / \mathrm{L})$, as compared to L-CETP $(594.4$ $\mathrm{mg} / \mathrm{L}$ ), which was mainly due to the presence of insoluble and soluble organic compounds.

In L-CETP, DO was very low ( $\left.4.39 \mathrm{mg} \mathrm{O}_{2} / \mathrm{L}\right)$ due to high concentration of pollutants and BOD values were also observed to be low - of $13.2 \mathrm{mg}$ $\mathrm{O}_{2} / \mathrm{L}$, indicating the water sample had a high load of heavy metals rather than other organic pollutants. An abnormally low $\mathrm{pH}$ (2.30) in the effluent sample can result in a significant decrease in the rate of removal of organic compounds from the effluent by reducing microbial activity, which can be responsible for a significantly low BOD value. On the other hand, sample 2 had a high value of DO $\left(9.20 \mathrm{mg} \mathrm{O}_{2} / \mathrm{L}\right)$, indicating that the water sample had an indigenous microflora. BOD values were observed to be high $(71.0 \mathrm{mg} / \mathrm{L})$ due to a high amount of organic matter from various chemicals used during the processing of hides and skins. It has been reported that a significant part of the chemicals used in the tanning process are not actually absorbed in the process and discharged into the environment. The L-CETP sample had high COD values (320 mg $\mathrm{O}_{2} / \mathrm{L}$ ), indicating the presence of biologically resistant organic materials, whereas J-CETP was found to have a value of $240 \mathrm{mg} \mathrm{O}_{2} / \mathrm{L}$, which was within the limits prescribed by the Central Pollution Control Board (CPCB) (i.e. $250 \mathrm{mg} \mathrm{O}_{2} / \mathrm{L}$ ).

The metal profile of the effluent samples was determined by using Inductively Coupled Argon Plasma-Atomic Emission Spectroscopy (ICAPAES). The results showed that, in the L-CETP effluent, among the major heavy metals of environmental concern, total $\mathrm{Cr}$ was found to be the dominant heavy metal contaminant with a concentration of $226.62 \mathrm{ppm}$, followed by nickel (28.12 ppm), lead (0.77 ppm) and cadmium (0.02 ppm). Sample 2 (J-CETP) was found to have a much lower concentration of these heavy metals of environmental concern, as compared to LCETP, whereby the concentration of total $\mathrm{Cr}$ was $1.83 \mathrm{ppm}$, followed by lead (0.39 ppm) and nickel $(0.10 \mathrm{ppm})$. As shown in Table 1, the permissible limit given by CPCB for the discharge of effluent is $0.1 \mathrm{ppm}$ for $\mathrm{Cr}, 3.0 \mathrm{ppm}$ for $\mathrm{Ni}$ and $0.1 \mathrm{ppm}$ for $\mathrm{Pb}$, indicating that the wastewater coming from both industries needs to be treated before its discharge into water bodies.

Earlier studies ${ }^{12-13}$ also reported that the $\mathrm{pH}$ of an electroplating industry effluent was 3 , with $\mathrm{COD}$ and BOD values of $240 \mathrm{mg} \mathrm{O}_{2} / \mathrm{L}$ and 8.08 $\mathrm{mg} \mathrm{O}_{2} / \mathrm{L}$, respectively. The values of $\mathrm{pH}$, temperature, EC, TDS, TSS, BOD and COD of electroplating industry effluents has been reported to be $2.5,25,1680 \mathrm{mS} / \mathrm{cm}, 360 \mathrm{mg} / \mathrm{L}, 675 \mathrm{mg} / \mathrm{L}$, $101 \mathrm{mg} \mathrm{O}_{2} / \mathrm{L}$ and $371 \mathrm{mg} \mathrm{O}_{2} / \mathrm{L}$, respectively. Similarly, for tannery effluents - the $\mathrm{pH}$, colour, EC, TS, TDS, COD and BOD were reported as: about 7.08, brown, 9070, 6867.3, 492, 2749.8 and 1099.2 , respectively. ${ }^{14}$ The heavy metal profile of the tannery effluent indicated that the concentration of chromium (total) was 106.51 $\mathrm{mg} / \mathrm{L}$, with hexavalent chromium $-3.67 \mathrm{mg} / \mathrm{L}$, trivalent chromium $-102.84 \mathrm{mg} / \mathrm{L}$, nickel -21.70 $\mathrm{mg} / \mathrm{L}$, copper $-2.78 \mathrm{mg} / \mathrm{L}$, zinc $-9.20 \mathrm{mg} / \mathrm{L}$ and cadmium $-0.35 \mathrm{mg} / \mathrm{L} .{ }^{15}$ Another study has also shown the presence of heavy metals in a tannery effluent, in which the concentrations of cadmium, lead, nickel, copper and zinc were $11.2 \mathrm{mg} / \mathrm{L}, 6.6$ $\mathrm{mg} / \mathrm{L}, \quad 2.3 \mathrm{mg} / \mathrm{L}, \quad 2.4 \mathrm{mg} / \mathrm{L}$ and $3.3 \mathrm{mg} / \mathrm{L}$, respectively. ${ }^{16}$ In 2015 , the metal species profile of an electroplating industry effluent indicated the concentration of calcium, magnesium, sodium, potassium and nickel ions to be of $273 \mathrm{mg} / \mathrm{L}, 255$ $\mathrm{mg} / \mathrm{L}, \quad 98 \mathrm{mg} / \mathrm{L}, 43 \mathrm{mg} / \mathrm{L}$ and $126 \mathrm{mg} / \mathrm{L}$, respectively. ${ }^{17}$

Biosorption is a process that is influenced by various operating parameters, such as $\mathrm{pH}$, temperature and initial metal concentration. Thus, for maximum biosorption of heavy metals, all these parameters were standardized.

\section{Influence of $\mathbf{p H}$}

The effect of $\mathrm{pH}$ on $\mathrm{Cr}$ biosorption by the spent mushroom compost of Agaricus bisporus, Pleurotus florida, Calocybe indica and 
Volvariella volvacea was studied over a $\mathrm{pH}$ range of 2-10, with continuous agitation at $250 \mathrm{rpm}$. It was observed that biosorption was high at acidic $\mathrm{pH}$ for all the four selected white rot fungi. This could have been due to high solubility of the metals in the $\mathrm{pH}$ range of 4-6. For the SMC of Agaricus bisporus, the $\mathrm{pH}$ of 4.0 was found to show maximum removal (\%) of total chromium, while for the SMC of Pleurotus florida, Calocybe indica and Volvariella volvacea, the optimum $\mathrm{pH}$ value was 6.0 (Fig. 2).

It has been illustrated that the optimum $\mathrm{pH}$ for biosorption by spent mushroom compost of Agaricus bisporus ${ }^{18}$ was 1.0. Meanwhile, another study reported that the optimum $\mathrm{pH}$ for biosorption of $\mathrm{Cr}$ (VI) by Pleurotus mutilis ${ }^{19}$ was around 5.4. Similarly, for $\mathrm{Pb}$, it has been reported that the optimum $\mathrm{pH}$ for biosorption of $\mathrm{Pb}$ by
Pleurotus florida ${ }^{20}$ was 7.0. The optimum $\mathrm{pH}$ for the removal of $\mathrm{Pb}$ by Calocybe indica ${ }^{16}$ was reported to be 5.0.

\section{Influence of temperature}

The adsorption on spent mushroom compost was studied in the temperature range of $15-45^{\circ} \mathrm{C}$. The maximum percent removal of $\mathrm{Cr}$ was achieved at a temperature of $25^{\circ} \mathrm{C}$ for Agaricus bisporus spent compost (60.63\%), Pleurotus florida spent compost $(72.45 \%)$ and Calocybe indica spent compost (66.09\%), whereas Volvariella volvacea spent compost showed $32.45 \%$ removal at $35{ }^{\circ} \mathrm{C}$ (Fig. 2). An increase in temperature in the suitable range increases the rate of adsorbate diffusion across the external boundary layer.
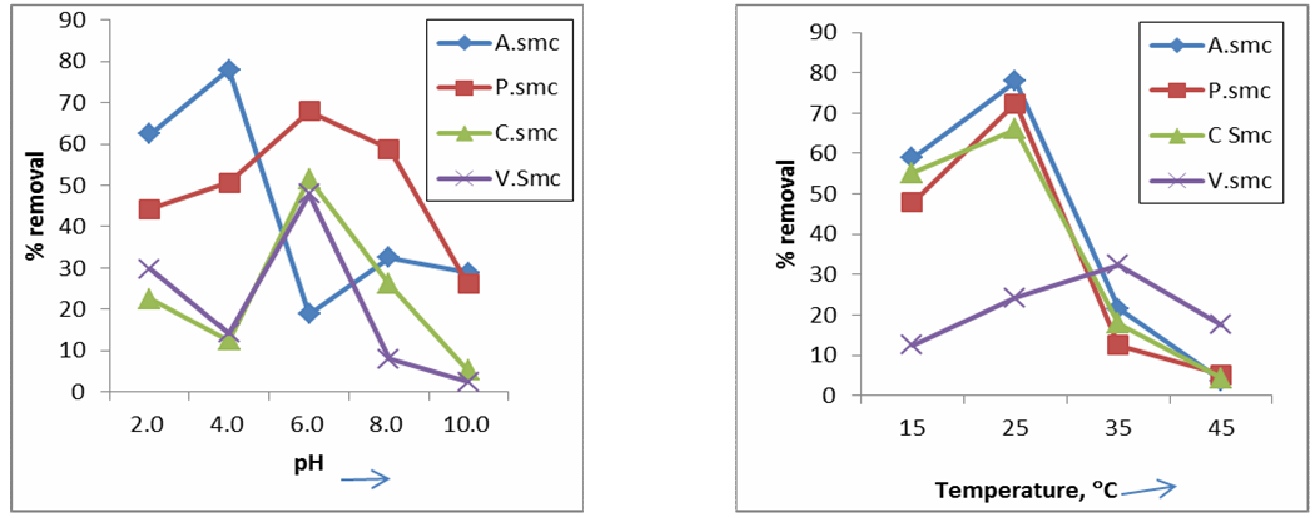

Figure 2: Influence of $\mathrm{pH}$ and temperature on biosorption of total $\mathrm{Cr}$ with SMC as adsorbent. Note: A.smc Agaricus bisporus based spent mushroom compost (SMC), P.smc - Pleurotus florida based SMC, C.smc Calocybe indica based SMC, V.smc - Volvariella volvacea based SMC
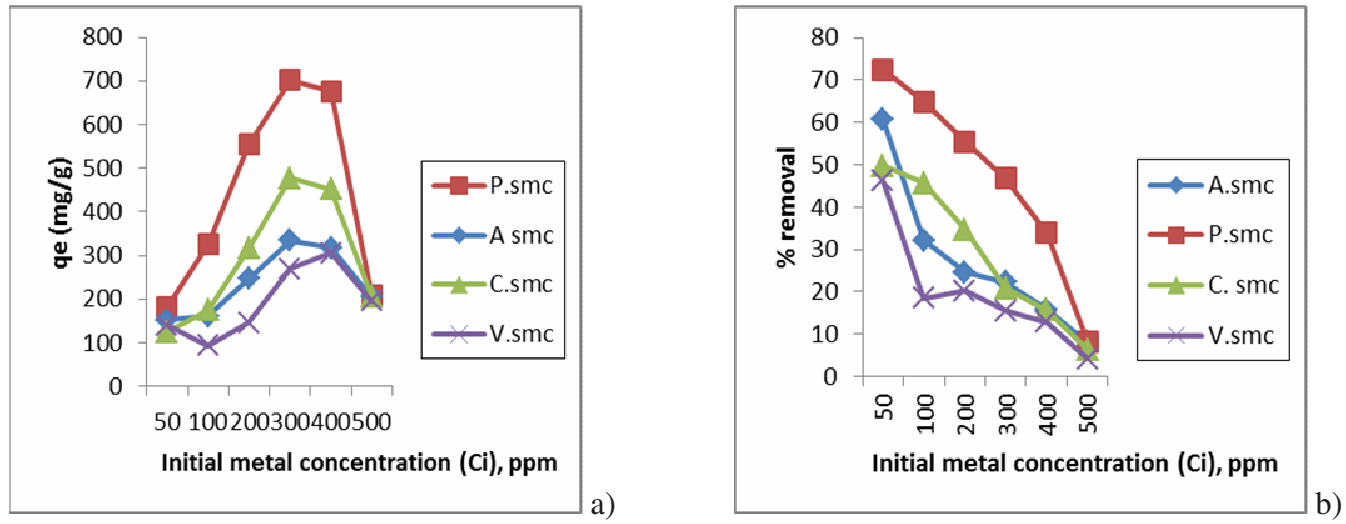

Figure 3: Influence of initial metal concentration on (a) sorption capacity and (b) removal of total $\mathrm{Cr}$ with SMC as adsorbent at optimized $\mathrm{pH}$ and temperature. Note: A.smc - Agaricus bisporus based SMC at $\mathrm{pH}$ 4.0 and temperature $25^{\circ} \mathrm{C}, \mathrm{P} . \mathrm{smc}-$ Pleurotus florida based SMC at pH 6.0 and temperature $25^{\circ} \mathrm{C}$, C.smc Calocybe indica based SMC at pH 6.0 and temperature $25^{\circ} \mathrm{C}$, V.smc - Volvariella volvacea based SMC at $\mathrm{pH} 6.0$ and temperature $35^{\circ} \mathrm{C}$ 
Earlier studies reported that the optimum temperature for biosorption by the spent mushroom compost of Agaricus bisporus and Pleurotus mutilis was $20^{\circ} \mathrm{C} .{ }^{18-19}$ A temperature of $28 \pm 2{ }^{\circ} \mathrm{C}$ has been found to be optimum for Calocybe indica for the removal of lead from aqueous solutions. ${ }^{16}$

\section{Influence of initial concentration of metal ions}

The initial metal concentration in the solution influences the equilibrium uptake of total $\mathrm{Cr}$. It was seen that increasing the initial metal concentration increases the sorption capacity, which was mainly due to the equilibrium process. A higher initial metal concentration provided an increased driving force necessary to overcome all mass transfer resistance of metal ions between the aqueous and the solid phases, resulting in higher probability of collision between metal surfaces, which results in a higher metal uptake. As illustrated in Figure 3a, the effect of varying initial metal concentration on the sorption capacity of all the selected spent mushroom compost types was studied. It was seen that with increasing initial metal concentration, after 300 ppm, a decline in sorption capacity was observed and the biosorbent showed a trend of saturation at high concentrations.
As illustrated in Figure $3 b$, the effect of varying initial metal concentration on the percent removal was studied for all the selected spent mushroom compost types. The concentration of $50 \mathrm{ppm}$ showed the maximum removal of $\mathrm{Cr}$ for Pleurotus florida SMC (72.45\%), followed by Agaricus bisporus SMC (60.63\%), Calocybe indica SMC (49.72\%) and Volvariella volvacea SMC (46.09\%).

In earlier studies, the optimum initial metal concentration for biosorption by the spent mushroom compost of Agaricus bisporus and Pleurotus mutilis was recorded to be $100 \mathrm{ppm} .^{18-19}$ Also, an initial metal concentration of $10 \mathrm{mg} / \mathrm{L}$ has been reported to be optimum for the removal of lead by Calocybe indica from aqueous solutions. ${ }^{16}$

\section{Adsorption isotherms}

The equilibrium of biosorption of heavy metals was modeled using adsorption isotherms. The Langmuir and Freundlich isotherms were applied to describe the adsorption equilibrium. The linearized plots of Ce/qe versus $\mathrm{Ce}$ are illustrated in Figure 4, and the Langmuir parameters were calculated from the slope and intercept of the graph.
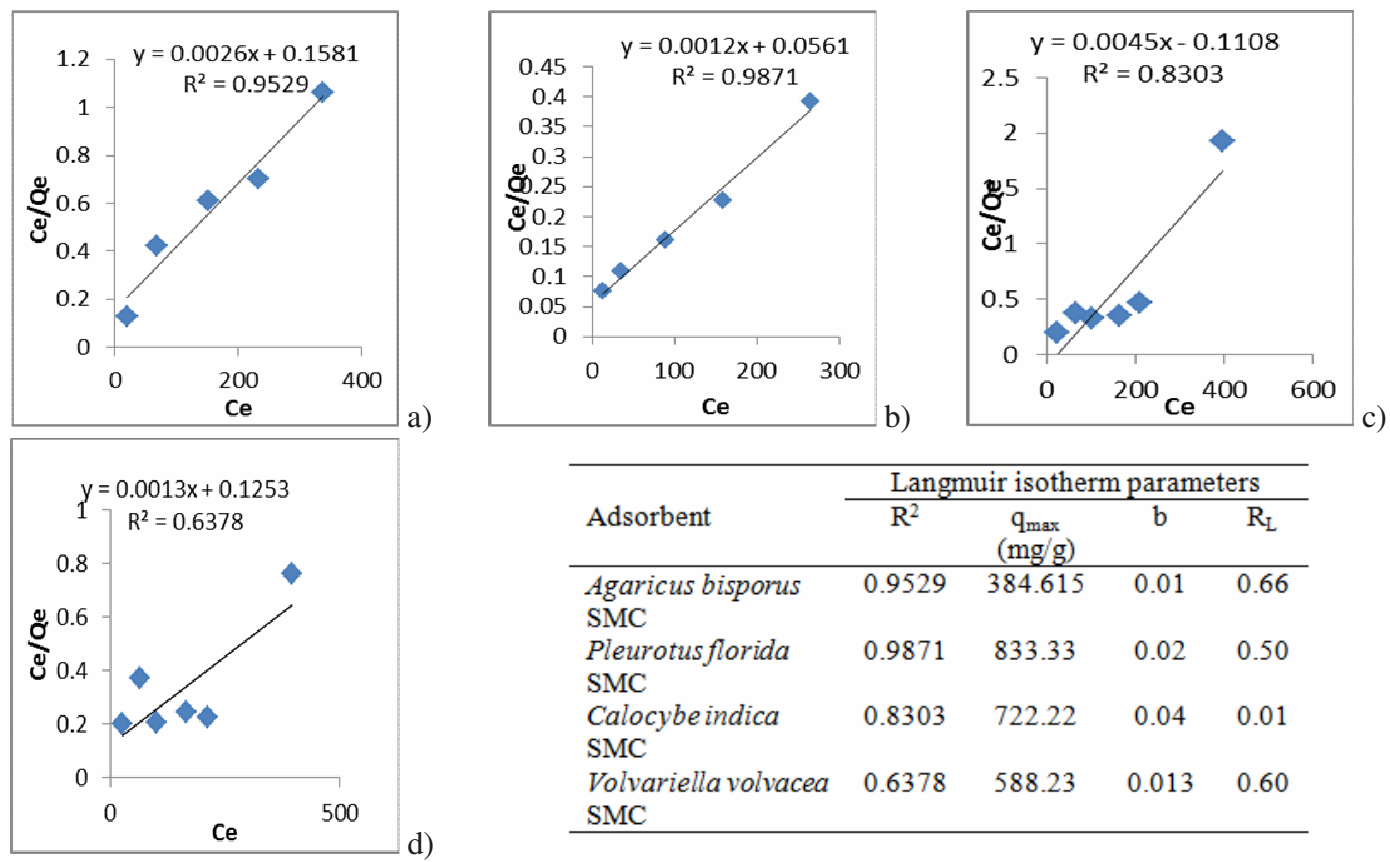

\begin{tabular}{lcccc}
\hline \multirow{2}{*}{ Adsorbent } & \multicolumn{4}{c}{ Langmuir isotherm parameters } \\
\cline { 2 - 5 } & $\mathrm{R}^{2}$ & $\begin{array}{c}\mathrm{q}_{\max } \\
(\mathrm{mg} / \mathrm{g})\end{array}$ & $\mathrm{b}$ & $\mathrm{R}_{\mathrm{L}}$ \\
\hline $\begin{array}{l}\text { Agaricus bisporus } \\
\text { SMC }\end{array}$ & 0.9529 & 384.615 & 0.01 & 0.66 \\
$\begin{array}{l}\text { Pleurotus florida } \\
\text { SMC }\end{array}$ & 0.9871 & 833.33 & 0.02 & 0.50 \\
$\begin{array}{l}\text { Calocybe indica } \\
\text { SMC }\end{array}$ & 0.8303 & 722.22 & 0.04 & 0.01 \\
$\begin{array}{l}\text { Volvariella volvacea } \\
\text { SMC }\end{array}$ & 0.6378 & 588.23 & 0.013 & 0.60 \\
\hline
\end{tabular}

Figure 4: Langmuir isotherms and isotherm parameters for (a) Agaricus bisporus, (b) Pleurotus florida, (c) Calocybe indica and (d) Volvariella volvacea as biosorbents 

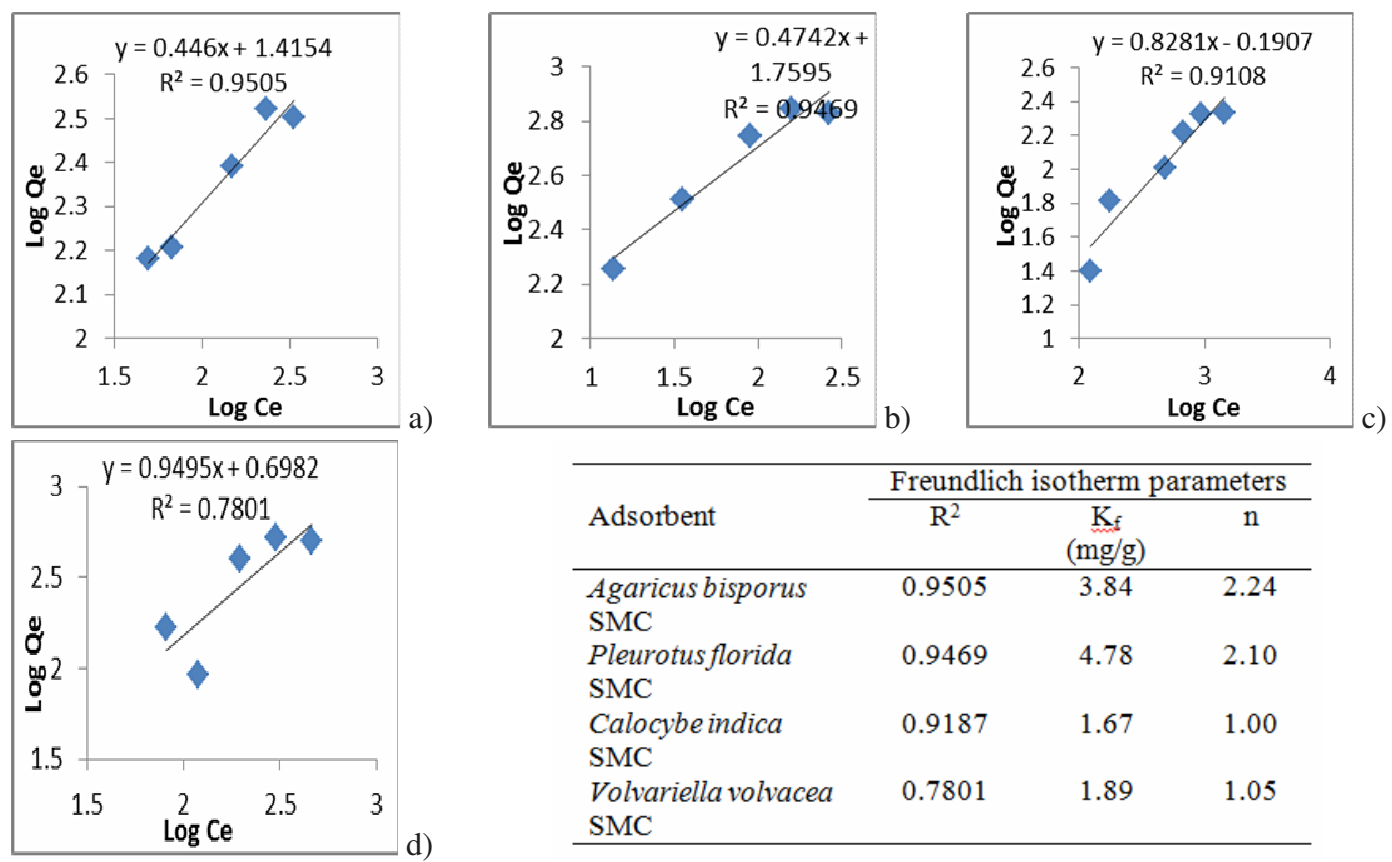

\begin{tabular}{lccc}
\hline \multirow{2}{*}{ Adsorbent } & \multicolumn{3}{c}{ Freundlich isotherm parameters } \\
\cline { 2 - 4 } & $\mathrm{R}^{2}$ & $\begin{array}{c}\mathrm{K}_{\mathrm{f}} \\
(\mathrm{mg} / \mathrm{g})\end{array}$ & $\mathrm{n}$ \\
\hline $\begin{array}{l}\text { Agaricus bisporus } \\
\text { SMC }\end{array}$ & 0.9505 & 3.84 & 2.24 \\
$\begin{array}{l}\text { Pleurotus florida } \\
\text { SMC }\end{array}$ & 0.9469 & 4.78 & 2.10 \\
$\begin{array}{l}\text { Calocybe indica } \\
\text { SMC }\end{array}$ & 0.9187 & 1.67 & 1.00 \\
$\begin{array}{l}\text { Volvariella volvacea } \\
\text { SMC }\end{array}$ & 0.7801 & 1.89 & 1.05 \\
\hline
\end{tabular}

Figure 5: Freundlich isotherms and isotherm parameters for (a) Agaricus bisporus, (b) Pleurotus florida, (c) Calocybe indica and (d) Volvariella volvacea as biosorbents

Further analysis of the Langmuir isotherm model was made by finding the value of $\mathrm{R}_{\mathrm{L}}$, the variation in the range of $0-1$ indicates a favourable adsorption process. The value of $\mathrm{R}_{\mathrm{L}}=$ 1 indicates that the adsorption is linear and if $\mathrm{R}_{\mathrm{L}}=$ 0 , it is irreversible. ${ }^{21}$ The value of $R_{L}$ was 0.66 , $0.50,0.01$ and 0.60 for $A$. bisporus, $P$. florida, $C$. indica and $V$. volvacea based SMC, indicating favourable adsorption for all the selected biosorbents of white rot fungi.

It has been reported the values of $\mathrm{R}^{2}, \mathrm{q}_{\max }$ and $\mathrm{b}$ to be $0.99,8.00 \mathrm{mg} / \mathrm{g}$ and 0.07 for Agaricus bisporus as adsorbent, and 0.916, 23.25 and 1.13 using Pleurotus mutilius as biosorbent. ${ }^{18-19}$ For biosorption of lead using Pleurotus florida as adsorbent, the values of $\mathrm{R}^{2}, \mathrm{q}_{\max }$ and $\mathrm{b}$ have been reported to be $0.967,12.19 \mathrm{mg} / \mathrm{g}$ and 0.058 , respectively. ${ }^{20}$ Vimala and Das (2009) reported the values of $\mathrm{R}^{2}, \mathrm{q}_{\max }$ and $\mathrm{b}$ to be 0.9972, 24.09, 0.04 , respectively, for biosorption of cadmium by Calocybe indica from aqueous solutions. ${ }^{16}$

The linearized plot of $\log \mathrm{C}_{\mathrm{e}}$ versus $\log \mathrm{q}_{\mathrm{e}}$ is given in Figure 5 and the estimated Freundlich isotherm parameters for the biosorption of $\mathrm{Cr}$ at an optimum temperature and $\mathrm{pH}$ are also mentioned, which were calculated from the graphical plot. The value of $1 / \mathrm{n}$ in the range of 1.0-10.0 indicates a favorable adsorption process. ${ }^{22}$ The findings illustrated the favorable adsorption process for all the selected biosorbents.
The values of $K_{f}, R^{2}$ and $n$ were found to be $1.79 \mathrm{mg} / \mathrm{g}, 0.97$ and 0.32 , respectively, with Agaricus bisporus spent compost as biosorbent, and $1.29 \mathrm{mg} / \mathrm{g}, 0.88,1.32$, respectively, with Pleurotus mutilus as adsorbent. ${ }^{18-19}$ Using Pleurotus florida as adsorbent, the values of $\mathrm{K}_{\mathrm{f}}$, $\mathrm{R}^{2}$ and $\mathrm{n}$ were shown to be $0.954,0.906$ and 1.61 , respectively, for biosorption of lead. ${ }^{20}$ Meanwhile, using Calocybe indica as biosorbent of cadmium from aqueous solutions, the values of $\mathrm{K}_{\mathrm{f}}, \mathrm{R}^{2}$ and $\mathrm{n}$ were reported to be $0.9498,2.27$ and 1.99, respectively. ${ }^{16}$ Here, $K_{\mathrm{f}}$ is an indicator of the adsorption capacity, a higher $\mathrm{K}_{\mathrm{f}}$ value indicates better adsorption capacity of the spent compost. Whereas $\mathrm{n}$ is a measure of the intensity of adsorption, a higher $1 / \mathrm{n}$ value indicates more favorable adsorption. Generally, $\mathrm{n}<1$ is required for favorable adsorption. A value of $\mathrm{n}$ higher than 1 indicates that the intensity of adsorption is very low.

\section{FTIR analysis}

The FT-IR spectra of the Agaricus bisporus compost mainly consist of two regions. The FTIR spectra before and after adsorption are shown in Figures 6 and 7, while Table 2 presents the band assignment for functional groups before and after adsorption. The first region lies in the wavenumber range of 1500-4000 $\mathrm{cm}^{-1}$ and represents the functional group region, indicating 
PRIYA KATYAL et al.

the presence of specific functional groups at different wavenumbers. Thus, a peak at $3400 \mathrm{~cm}^{-1}$ indicates the presence of the N-H group. Another peak in the region of $2800-3000 \mathrm{~cm}^{-1}$ indicates the $\mathrm{CH}$ group, while that in the range of 2400-3000 $\mathrm{cm}^{-1}$ indicates the presence of the $\mathrm{OH}$ group. The absence of bands in the region of $2100-2200 \mathrm{~cm}^{-1}$ indicates the absence of $\mathrm{C} \equiv \mathrm{N}$ and $\mathrm{C} \equiv \mathrm{C}$ bonds, whereas the presence of a number of bands in the region of $1600-1800 \mathrm{~cm}^{-1}$ indicates the presence of $\mathrm{C}=\mathrm{O}$ bonds, which can be associated with complex ring deformation. The second region lies within the wavenumber range of $500-1500 \mathrm{~cm}^{-1}$ and is called as the fingerprint region, which indicates multiple bond deformation. The characteristic bands in the range of 1027-1048 $\mathrm{cm}^{-1}$ are indicative of the presence of complex polysaccharides. The multiple peaks at 3200-3500 $\mathrm{cm}^{-1}$ indicate $\mathrm{O}-\mathrm{H}$ bond stretching vibrations.

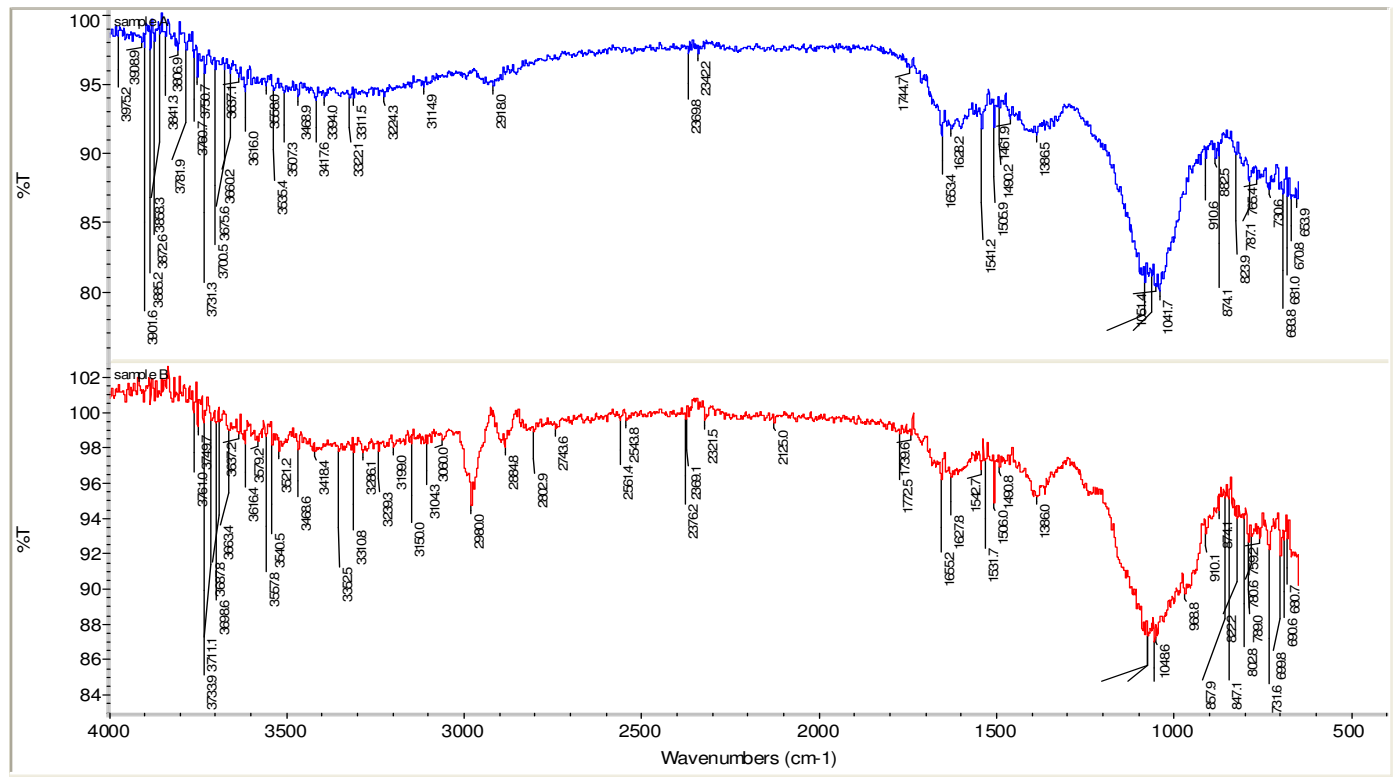

Figure 6: FT-IR spectra of Agaricus bisporus SMC (a) before biosorption and (b) after biosorption of sample 1 (L-CETP)

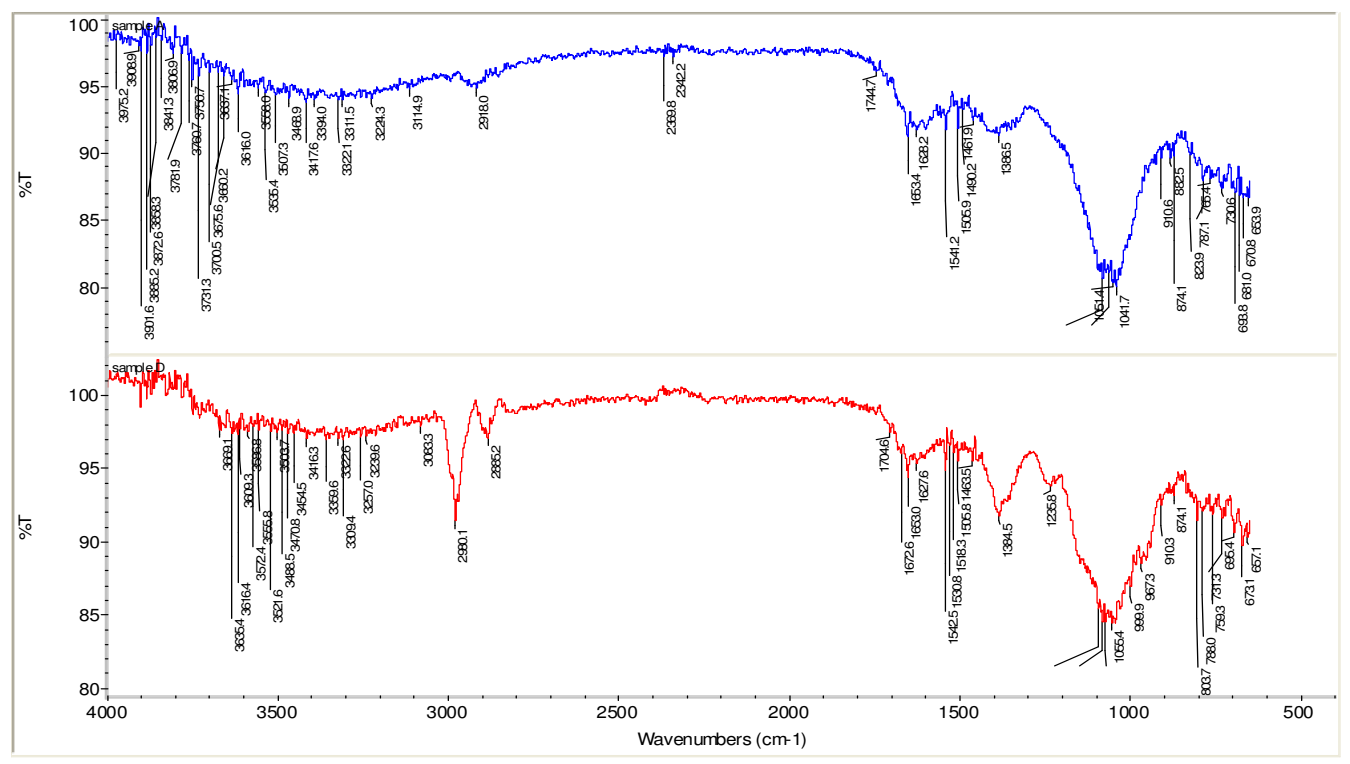

Figure 7: FT-IR spectra of Agaricus bisporus SMC (a) before biosorption and (b) after biosorption of sample 2 (J-CETP) 
Lignocellulose

Table 2

FT-IR spectra of spent mushroom compost before and after adsorption

\begin{tabular}{ccccc}
\hline \multirow{2}{*}{$\begin{array}{c}\text { IR } \\
\text { peak }\end{array}$} & \multicolumn{3}{c}{ Adsorption bands $\left(\mathrm{cm}^{-1}\right)$} & \multirow{2}{*}{ Inference } \\
\cline { 2 - 4 } & Before adsorption & After adsorption & Differences & \\
\hline 1 & 2918 & 2884.8 & -33.2 & Stretching of $\mathrm{CH}$ and $\mathrm{CH}_{2}$ group \\
2 & 1041 & 1048 & +7 & Differences in polysaccharides \\
3 & 1744.7 & 1739.6 & -5.1 & Masking of protonated carboxyl group \\
4 & 2342.2 & 2321.5 & +20.7 & Carboxylic group O-H bond stretch \\
\hline
\end{tabular}

In comparison with the control sample A, showing the peak at $1744.7 \mathrm{~cm}^{-1}$, the treated sample (1) exhibited the peak at $1739.6 \mathrm{~cm}^{-1}$. This peak corresponds to the presence of ketones, quinones and carboxylic acid esters. A similar shift was seen at the position $2918 \mathrm{~cm}^{-1}$, which was present in the control sample A, but shifted to $2980 \mathrm{~cm}^{-1}$ in the treated sample, indicating the stretching of $\mathrm{C}-\mathrm{H}$ and $\mathrm{CH}_{2}$ group. The characteristic peak at $1506.9 \mathrm{~cm}^{-1}$ in the control and $1506.0 \mathrm{~cm}^{-1}$ in the treated sample indicates the presence of lignin. The presence of the peak at $1653.4 \mathrm{~cm}^{-1}$ in the control sample and at 1655.2 $\mathrm{cm}^{-1}$ in the treated sample indicated the presence of the $\mathrm{CO}_{2}$ stretch of the carboxylic group and aliphatic alkanes. Similar variations have also been observed while comparing the control sample with sample (2).

A comparison of the adsorption capacity of SMC of different fungi (A. bisporus, $P$. florida, $C$. indica and $V$. volvacea) indicated maximum adsorption achieved by $P$. florida based SMC, showing a $\mathrm{q}_{\max }$ value of $833.33 \mathrm{mg} / \mathrm{g}$ (Fig. 4) and a $\mathrm{K}_{\mathrm{f}}$ value of 4.78 (Fig. 5). This can be related to the high lignolytic ability of $P$. florida, as compared to the other fungal genera used here. Higher lignolytic activity resulted in the creation of more voids for binding of the metal. The $P$. florida based SMC, therefore, can be used as an environmentally friendly effective and low-cost adsorbent.

\section{CONCLUSION}

Based on the results obtained in the present study, it can be suggested that spent mushroom compost can be considered as a cost-effective biosorbent for removing heavy metals from aqueous media. The high $\mathrm{q}_{\max }$ and $\mathrm{K}_{\mathrm{f}}$ values of the SMC revealed its great potential as an adsorbent of heavy metals. Thus, the spent mushroom compost has a great potential to be developed into a green remediation technology due to its high uptake capacity, the possibility to reuse the biosorbent and recover the metals from it. More in-depth studies are required to be done to further explore the potential of spent mushroom compost for possible heavy metal bioremediation of effluent wastewater.

ACKNOWLEDGEMENTS: The authors are highly thankful to Dr Rajeev Sikka from the Department of Soil Science, Punjab Agricultural University, Ludhiana, for providing the facility for heavy metal analysis by ICAP-AES.

\section{REFERENCES}

1 M. M. Lasat, J. Environ. Qual., 31, 109 (2002), https://doi.org/10.2134/jeq2002.1090

2 V. N. Kavamura and E. Esposito, Biotechnol. Adv., 28 , 61

(2010), https://doi.org/10.1016/j.biotechadv.2009.09.00

3 L. Santona, P. Castaldi and P. Melis, J. Hazard. Mater., $\quad$ 136, $324 \quad$ (2006), https://doi.org/10.1016/j.jhazmat.2005.12.022

4 K. Pakshiranjan, N. Worku, M. A. Acheampong, H. J. Lubberding and P. N. Lens, Appl. Biochem. Biotechnol., $\quad \mathbf{1 7 0}, \quad 498 \quad$ (2013), https://doi.org/10.1007/s12010-013-0202-6

5 Y. Zhou, J. Lie, Y. Zhang, J. Zhu, Y. Lu et al., Water, 10, $1248 \quad$ (2018), https://doi.org/10.3390/w10091248

6 G. G. Chen, G. Zeng, L. Tang, C. Dua, X. Jiang et al., J. Environ. Sci., 17, $756 \quad$ (2005), https://scialert.net/eboardlivedna.php?issn=18193412\&id $=1.8517$

7 H. Siasar and F. Sargazi, Int. J. Rev. Life Sci., 5, 925 (2015)

8 APHA American Public Health Association, "Standard Methods for the Examination of Water and Wastewater, $20^{\text {th }}$ ed., Washington D.C., (2001), http://www.worldcat.org/oclc/779509419

9 S. Panchagnula and $\mathrm{N}$ Chintamani, Int. J. Res. Appl. Sci. Eng. Technol., 6, 2023 (2018), https://doi.org/10.22214/ijraset.2018.1316

10 K. Y. Foo and B. H. Hameed, Chem. Eng. J., 156, 2 (2010), https://doi.org/10.1016/j.cej.2009.09.013

11 A. N. Kamarudzaman, C. C. Tay, A. Amnorzahira, H. H. Liew and S. Abdul-Talib, Adv. Environ. Biol., 8, 1 (2014), http://www.aensiweb.com

12 M. Periyasamy and M. R. Rajan, J. Ind. Poll. $\begin{array}{llll}\text { Control., } & \mathbf{2 5}, & 1 & \text { (2009), }\end{array}$ http://www.icontrolpollution.com 
13 V. Singh, C. Ram and A. Kumar, J. Civil Environ. Eng., 6, 237 (2016), https://doi.org/10.4172/2165784X. 1000237

14 A. Sugasini and K Rajagopal, Int. J. Curr. Microbiol. Appl. Sci., 4, 349 (2015), http://www.ijcmas.com

15 M. Z. Alam, S. Ahmad and A. Malik, Environ. Monit. Assess., 178, $281 \quad$ (2011), https://doi.org/10.1007/s10661-010-1689-8

16 R. Vimala and N. Das, J. Hazard. Mater., 168, 376 (2009), https://doi.org/10.1016/j.jhazmat.2009.02.062

17 M. Poonkothai and S. B. Vijayavathi, Int. Res. J. Pharma Biosci., 2, 1 (2015), http://www.irjpbs.com

18 N. Ertugay and Y. K. Bayhan, J. Hazard. Mater., 154, 432 (2008),
19 A. Alouache, A. Selatnia and F. Halet, in "Frontiers in Wastewater Treatment and Modelling", edited by G. Mannina, Springer International Publishing AG, Switzerland, 2017, pp. 368-375, http://www.springer.com

20 A. S. A. Prasad, G. Varatharaju, C. Anushri and S. Dhivyasree, Brit. Biotech. J., 3, 66 (2013), https://doi.org/10.9734/BBJ/2013/2348

21 M. K. Rai, G. Shahi, V. Meena, R. Meena, S. Chakraborty et al., Res. Efficient Technol., 2, 63 (2016), https://doi.org/10.1016/j.reffit.2016.11.011

22 T. Fan, Y. G. Liu, B. Y. Feng, G. M. Zeng, C. P. Yang et al., J. Hazard. Mater., 160, 655 (2008), https://doi.org/10.1016/j.jhazmat.2008.03.038

https://doi.org/10.1016/j.jhazmat.2007.10.070 